\title{
Effect of Mechanical Analysis of Magnesium AZ 80 Alloy and Aluminium 7075 Alloy using Diffusion Bonding
}

\author{
R. J. Golden Renjith Nirmal, Sabarish R, Lenin Rakesh N
}

\begin{abstract}
The vital issue when joining magnesium combination (Mg) and aluminum composite (Al) exists in the presence of development of oxide movies and fragile intermetallic inside the bond district. Be that as it may, dispersion welding is acclimated be a piece of these amalgams while not a great deal of issue. In this examination, an endeavor was made to break down the mechanical properties, for example, lap shear quality, Ram rigidity and microhardness for dispersion holding of AZ80 magnesium (Mg) and AA7075 aluminum (Al) disparate materials. The holding nature of the joints was checked by microstructure examination. This work is directed to get better understanding and portrayal of the dissemination holding of comparative and different metals. It additionally meant to acquire ideal parameters for dispersion holding of aluminum covering over magnesium composite with Aluminum amalgam. This work is led to get better understanding and portrayal of the dispersion holding of comparable and different metals. It additionally intended to get ideal parameters for dispersion holding of aluminum covering over magnesium composite with aluminum amalgam. These two metals are jointed inside the kick the bucket in the wake of completing surface treatment.
\end{abstract}

Keyword : Micro Hardness, Composite Materials

\section{INTRODUCTION}

Dissemination holding is a strong state joining process where in the important system is bury dispersion of particles over the interface. Dispersion holding of most metals is directed in vacuum or in an idle environment (typically dry nitrogen, argon or helium) so as to diminish hindering oxidation of the faying surfaces. Another approach to characterize the dissemination holding is a strong state welding process by which two cleaned surfaces are joined at raised temperature and under applied weight[1],[3],[5]. Aluminum is the most overflowing metal accessible in the world's hull. It is likewise a shopper metal critical. This turns into a solid contender for steel in different Engineering applications. The 7075 aluminum compounds are generally utilized because of their brilliant mix of mechanical properties and consumption obstruction.

\begin{tabular}{|l|c|c|}
\hline Mechanical Properties & Mg alloy & Al alloy \\
\hline Density (Kg/m $\left.{ }^{3}\right)$ & $1.78 \times 10^{3}$ & $2.9 \times 10^{3}$ \\
\hline $\begin{array}{l}\text { Ultimate Tensile } \\
\text { strength (MPa) }\end{array}$ & 351 & 580 \\
\hline Elongation (\%) & 17 & 11 \\
\hline Shear strength (MPa) & 199 & 342 \\
\hline
\end{tabular}

Table 1: Mechanical properties of the base metal

The mechanical properties and the compound piece of both aluminum and magnesium amalgams are given in the tables 1 and 2 .

\begin{tabular}{|c|c|c|}
\hline $\begin{array}{c}\text { Chemical } \\
\text { Compositions }\end{array}$ & $\begin{array}{c}\text { AZ80 } \\
\text { Mg alloy }\end{array}$ & $\begin{array}{c}\text { AA7075 Al } \\
\text { alloy }\end{array}$ \\
\hline $\mathrm{Al}$ & 8.36 & 90.02 \\
\hline $\mathrm{Zn}$ & 0.75 & 5.1 \\
\hline $\mathrm{Mn}$ & 0.26 & 0.30 \\
\hline $\mathrm{Fe}$ & 0.0037 & 0.50 \\
\hline $\mathrm{Ti}$ & - & 0.20 \\
\hline $\mathrm{Si}$ & 0.033 & 0.40 \\
\hline
\end{tabular}

\begin{tabular}{|c|c|c|}
\hline $\mathrm{Cu}$ & 0.002 & 1.2 \\
\hline $\mathrm{Ni}$ & 0.00056 & - \\
\hline $\mathrm{Cr}$ & - & 0.18 \\
\hline $\mathrm{Mg}$ & 90.591 & 2.1 \\
\hline
\end{tabular}

Table 2: Chemical Composition of the base metal

\section{EXPERIMENTAL ANALYSIS}

Revised Manuscript Received on August 22, 2019.

R. J. Golden Renjith Nirmal, Department of Mechanical Engineering, Bharath Institute of Higher Education and Research, Chennai, Tamilnadu, India. Email: goldenrenjith@gmail.com

Sabarish R, Department of Mechanical Engineering, Bharath Institute of Higher Education and Research, Chennai, Tamilnadu, India. Email: sabarish5041@gmail.com

Lenin Rakesh N, Department of Mechanical Engineering, Bharath Institute of Higher Education and Research, Chennai, Tamilnadu, India. Email: leninrakesh@gmail.com 
The cleaned and with synthetic concoctions treated examples were stacked in a very kick the bucket made of $316 \mathrm{~L}$ hardened steel and furthermore the whole dispersion holding arrangement, appeared in Fig. 2, was embedded into a chamber (vacuum weight of a hundred and forty weight unit is kept up). The examples territory unit het up to the holding temperature exploitation enlistment chamber with a warming pace of $250 \mathrm{C} / \mathrm{min}$; parallel the predetermined weight was applied. when the consummation of holding, the examples zone unit cooled to temperature before expulsion from the chamber. twenty seven preliminaries of unique joints region unit invented exploitation totally various combos of holding temperature, holding weight and holding time[2],[4],[6].

\section{A. Effect of Pressure}

\begin{tabular}{|c|c|c|c|c|}
\hline Sl. No & Temperature & Pressure & Time & Remarks \\
\hline 1. & 400 & 2 & 15 & Not Bonded \\
\hline 2. & 400 & 5 & 15 & Bonded \\
\hline 3. & 400 & 10 & 15 & Bonded \\
\hline 4. & 400 & 15 & 15 & Bonded \\
\hline 5. & 400 & 20 & 15 & Bonded \\
\hline 6. & 400 & 25 & 15 & Deformed \\
\hline
\end{tabular}

Table 3: Bonded samples

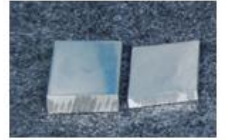

(a) Not Bonded Specimen

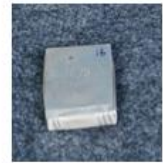

(b) Bonded Specimen

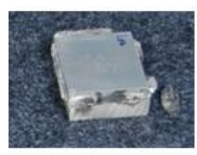

(c) Deformed Specimen

\section{RESULTS AND DISCUSSION}

The center layer of AZ80 Mg composite/AA7075 Al combination dispersion justified joint made the plain dissemination between the Az80 Mg amalgam substrate and along these lines the AA7075 $\mathrm{Al}$ compound substrate inside the state of the dissemination holding. After the holding technique, the full scale distortion isn't learned at the justified examples[7],[9],[11]. All justified examples were made with sound holding with none little pores, smaller scale split and compound. The new splendid area is made at the interface with regards to $\mathrm{Mg}-\mathrm{Al}$ segment outline, the new segment of $\mathrm{Mg}$ - $\mathrm{Al}$ intemetallics is made once the holding weight is $2 \mathrm{MPa}$ to $25 \mathrm{MPa}[8],[10],[12]$. There is an obvious limit between the AA7075 Al compound substrate and in this way the dissemination zone. In any case, the limit isn't clear between the Az80 Mg amalgam substrate and subsequently the dispersion zone. The examples are set up for Lap shear and Ram Tensile test.

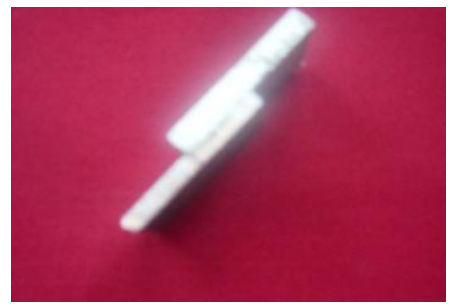

Figure - 1Lap shear test specimen

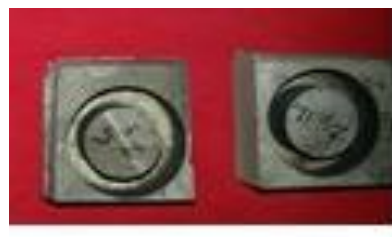

Before Testing

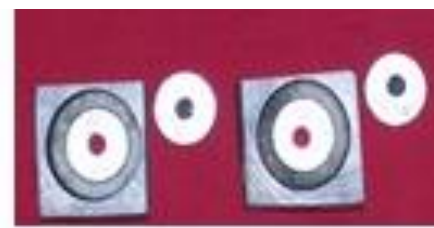

After Testing

\begin{tabular}{|c|c|c|c|c|c|}
\hline $\begin{array}{c}\text { Sample } \\
\text { No }\end{array}$ & $\begin{array}{c}\text { Bonding } \\
\text { Temperature } \\
\text { 'C }\end{array}$ & $\begin{array}{c}\text { Bonding } \\
\text { Pressure } \\
\text { MPa }\end{array}$ & $\begin{array}{c}\text { Bonding } \\
\text { Time } \\
\text { min }\end{array}$ & $\begin{array}{c}\text { Lap Shear } \\
\text { MPa }\end{array}$ & $\begin{array}{c}\text { Ram Tensile } \\
\text { MPa }\end{array}$ \\
\hline 1. & 400 & 5 & 15 & 13 & 19 \\
\hline 2. & 400 & 10 & 15 & 23 & 29 \\
\hline 3. & 400 & 15 & 15 & 21 & 31 \\
\hline 4. & 400 & 20 & 15 & 20 & 27 \\
\hline
\end{tabular}

Table 4: Lap shear and Ram Tensile Test Results

\begin{tabular}{|c|c|c|c|c|c|c|}
\hline \multirow[b]{2}{*}{$\begin{array}{c}\text { Sample } \\
\text { No }\end{array}$} & \multirow[b]{2}{*}{$\begin{array}{c}\text { Bonding } \\
\text { Temperature } \\
\text { 'C }\end{array}$} & \multirow[b]{2}{*}{$\begin{array}{c}\text { Bonding } \\
\text { Pressure } \\
\text { MIPa }\end{array}$} & \multirow[b]{2}{*}{$\begin{array}{c}\text { Bonding } \\
\text { Time } \\
\text { min }\end{array}$} & \multirow[b]{2}{*}{$\begin{array}{c}\mathrm{X} \text {-axis } \\
\mathrm{Hx}\end{array}$} & \multicolumn{2}{|c|}{$\mathrm{Y}$-axis } \\
\hline & & & & & $\begin{array}{l}\text { Al } \\
\text { Side } \\
\text { Hx }\end{array}$ & $\begin{array}{l}\text { Mg } \\
\text { Side } \\
\text { Hy }\end{array}$ \\
\hline 1. & 400 & 5 & 15 & 96.833 & 85.6 & 97.7 \\
\hline 2. & 400 & 10 & 15 & 70.833 & 75.4 & 83.3 \\
\hline 3. & 400 & 15 & 15 & 102.066 & 66.7 & 102 \\
\hline 4. & 400 & 20 & 15 & 71.366 & 84.3 & 106 \\
\hline
\end{tabular}

Table 5: Results of Micro hardness Test

\section{CONCLUSION}

The improvement of holding parameters for dissemination holding magnesium AZ80 compound and aluminum AA7075 combination are to be diffused in a dispersion holding machine and the bite the dust is kept inside the dispersion holding machine by shifting the time, temperature, weight by methods for burden. Before making dissemination holding hardware, tests are directed with high costly and straightforward installation which is kept inside an enlistment heater in cinching position to get dispersion reinforced joints. Hot press dispersion holding hardware is manufactured and checked with tests so it is equipped for rendering exact dissemination holding joints with offices to gauge parameters and to research the too plastic dispersion holding joints. This technique is formulated to consider the physical marvels that have noteworthy effect on dissemination holding, for example, time, temperature, weight on joints and metallurgical qualities. Smash Tensile and Lap shear tests are to be directed and miniaturized scale hardness test are additionally led. For the dispersion holding of Az80 Magnesium compound and AA7075 Aluminum combination, the most extreme shear quality was gotten for the example fortified at $400 \mathrm{oC}, 15 \mathrm{MPa}$ and 15 minutes. The elastic shear quality of the reinforced examples was observed to be expanded with expanding temperature until a greatest worth is come to past which it diminished. 


\section{REFERENCES}

1. Tatikonda, N.C. \& Naveenchandran, P. 2019, "The behaviour of a compression ignition engine under the influence of diesel and microalgae biodiesel blends", International Journal of Mechanical and Production Engineering Research and Development, vol. 9, no. 4, pp. 447-456.

2. Tatikonda, N.C. \& Naveenchandran, P. 2019, "An experimental assessment on the impact of injection pressure on the characteristics of a diesel engine powered with the blend of diesel and microalgae biodiesel", International Journal of Engineering and Advanced Technology, vol. 8, no. 6, pp. 3284-3291.

3. Karthikeyan, S., Raman Balasubramanian, S.R., Ramesh, B., Raghul, S. \& Sathish Kumar, S. 2019, "The automatic solar tracker chronicles", International Journal of Recent Technology and Engineering, vol. 8, no. 1, pp. 312-315.

4. Hema, R., Sundararajan, M. \& Balaji, S. 2019, "Smartphone control robot with automatic firing gun", International Journal of Innovative Technology and Exploring Engineering, vol. 8, no. 9 Special Issue 3, pp. 625-627.

5. Saritha, B., Chockalingam, M.P. \& Aswathy, M. 2019, "Degradation of anionic dye using $\mathrm{Fe} / \mathrm{Tio} 2$ composite by photocatalysis", International Journal of Innovative Technology and Exploring Engineering, vol. 8, no. 9 Special Issue 3, pp. 788-791.

6. Saritha, B., Maria Subashini, L. \& Aswathy, M. 2019, "Utilization of spent coffee grounds for compost production", International Journal of Innovative Technology and Exploring Engineering, vol. 8, no. 9 Special Issue 3, pp. 908-910.

7. Fernando, J.K., Meikandaan, T.P. \& Hemapriya, M. 2019, "Better utilisation of bottom ash in coal fired thermal power station", International Journal of Innovative Technology and Exploring Engineering, vol. 8, no. 9 Special Issue 3, pp. 898-900.

8. Kumar, K.S., Kiruthiga, K. \& Thendral, S. 2019, "Experimental analysis on fractional substitution of bond by utilizing rice husk cinder", International Journal of Innovative Technology and Exploring Engineering, vol. 8, no. 9 Special Issue 3, pp. 1163-1165.

9. Vignesh, P., Madan, P., Mohankumar, D. \& Naveenchandran, P. 2019, "Optimization of four stroke c.i. engine performance by using statistical techniques (mathematical method)", International Journal of Recent Technology and Engineering, vol. 8, no. 2, pp. 1685-1691.

10. Bharanidharan, S., Sathiyamurthy, K. \& Sheeba, B. 2019, "Using co-precipitation method determining synthesis and characterization of fe doped zinc oxide nanoparticles", International Journal of Innovative Technology and Exploring Engineering, vol. 8, no. 9 Special Issue 3, pp. 705-707.

11. Jeevanandan, D. \& Vino, J.A. 2019, "Heat recovery from boiler blowdown water by using heat exchanger in thermal power plant", International Journal of Mechanical and Production Engineering Research and Development, vol. 9, no. 3, pp. 219-222.

12. Rakesh, N.L., Balambica, V. \& Kannan, S. 2019, "Biogas extraction from waste orange peel by digestion process", International Journal of Mechanical and Production Engineering Research and Development, vol. 9, no. 3, pp. 323-330.

13. Meenakshi, C.M. \& Krishnamoorthy, A. 2019, "The mechanical characterization of mono and hybrid fiber reinforced composites using experimental and finite element analysis methods", International Journal of Mechanical and Production Engineering Research and Development, vol. 9, no. 3, pp. 189-196.

14. Mohankumar, D., Prem Jayakumar, M., Sabarsish, R. \& Naveen Chandran, P. 2019, "Modeling and experimental investigation on centrifugal blower by computational fluid dynamics", International Journal of Mechanical and Production Engineering Research and Development, vol. 9, no. 3, pp. 331-340.

15. Balambica, V., Deepak, V. \& Kumar, S. 2019, "Design and efficiency of an asymmetric gear", International Journal of Mechanical and Production Engineering Research and Development, vol. 9, no. 3, pp. 223-230.

16. Manavalan, S., Balakrishnan, G. \& Ramasubramaniam, S. 2019, "An effect of cobalt oxide nano additive with biodiesel blends using cidi diesel engine", International Journal of Mechanical and Production Engineering Research and Development, vol. 9, no. 3, pp. 211-218.

17. Golden Renjith Nimal, R.J., Sivakumar, M. \& Esakkimuthu, G. 2019, "An investigation on mechanical properties and microstructure of $\mathrm{mg} / \mathrm{al}$ alloys using $\mathrm{zn}$ interlayer during diffusion bonding", International Journal of Mechanical and Production Engineering Research and Development, vol. 9, no. 3, pp. 125-130.
18. Hariharan, R., Raja, R. \& Vasu, S. 2019, "Mechanical and tribological behaviour of thin tan coating produced on AISI 1018 substrate by DC magnetron sputtering", International Journal of Recent Technology and Engineering, vol. 7, no. 6, pp. 591-598

19. Manavalan, S., Rai, R., Kumar, R.R., Chaudhary, R.K. \& Chaudhary, S.K. 2019, "Impact of modified piston - A review", International Journal of Recent Technology and Engineering, vol. 8, no. 6, pp 616-620.

20. Manavalan, S., Gopi, A., Arivarasu, J., Abishek Ahi, A. \& Chandru, S. 2019, "Review on ceramic disc brake system", International Journal of Recent Technology and Engineering, vol. 7, no. 6, pp. 612-615.

21. Sabarish, R. \& Jeya Kumar, M.P. 2019, "The design and analysis of piston - Steady state thermal analysis using "ansys"", International Journal of Mechanical and Production Engineering Research and Development, vol. 9, no. 3, pp. 197-204.

22. Ravi, D. 2019, "CFD simulation of solar loading in car", International Journal of Mechanical and Production Engineering Research and Development, vol. 9, no. 3, pp. 231-236.

\section{AUTHORS PROFILE}

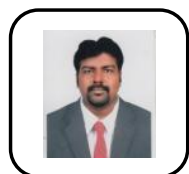

R. J. Golden Renjith Nirmal Assistant Professor, Department of Mechanical Engineering, Bharath Institute of Higher Education and Research, Chennai, India.

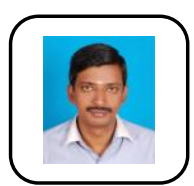

Sabarish R Assistant Professor, Department of Mechanical Engineering, Bharath Institute of Higher Education and Research, Chennai, India.

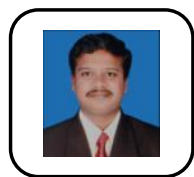

Lenin Rakesh N Assistant Professor, Department of Mechanical Engineering, Bharath Institute of Higher Education and Research, Chennai, India. 